Int. J. Dev. Biol. 59: 141-147 (2015)

doi: $10.1387 / \mathrm{ijdb} .150084 \mathrm{el}$

\title{
Combinatorial cancer immunotherapy strategies with proapoptotic small-molecule IAP antagonists
}

\author{
SHAWN T. BEUG ${ }^{1}$, DAVID P. CONRAD ${ }^{1,2}$, TOMMY ALAIN ${ }^{1,3}$, ROBERT G. KORNELUK ${ }^{1,3}$ and ERIC C. LACASSE ${ }^{*, 1}$ \\ 'Solange Gauthier Karsh Molecular Genetics Laboratory, Apoptosis Research Centre, Children's Hospital of Eastern \\ Ontario (CHEO) Research Institute and ${ }^{2}$ Celverum Inc., Ottawa, Canada; ${ }^{3}$ Department of Biochemistry, Microbiology \\ and Immunology, University of Ottawa, Ottawa, Canada
}

\begin{abstract}
Members of the inhibitor of apoptosis (IAP) family control several critical aspects of innate immunity, cell death, and tumorigenesis. Small molecule antagonists that target specific IAP oncoproteins, primarily cIAP1 and cIAP2, but potentially also XIAP and Livin, modulate distinct immune signal transduction pathways that can lead to an increased sensitivity of tumors cells to cytokine-mediated apoptosis. These antagonists are based on the structure of an endogenous cellular IAP inhibitor called Smac. Smac is normally sequestered within the mitochondria and is released into the cytoplasm upon cell death stimuli, thereby overcoming the anti-apoptotic action of the IAPs. The therapeutic usefulness of recombinant tumoricidal cytokines to treat cancer patients is principally limited due to their unacceptable adverse side effects. Therefore, investigators have sought to develop alternative regimens that do not rely on exogenously delivered death ligands. These approaches include the stimulation of the immune system with oncolytic virus-based agents or Toll-like receptor agonists in combination with Smac mimetics. Similarly, preclinical combination immunotherapy studies reveal that recombinant interferon synergizes with Smac mimetics to kill cancer. This strategy opens up new therapeutic avenues for anti-cancer therapy by modulating specific immune-mediated death pathways employing unique dual-pronged combinatorial approaches.
\end{abstract}

KEYWORDS: Smacmimetic, XIAP, cIAP1, cIAP2, TNF , interferon, oncolytic virus, TLR agonist, virotherapy, apoptosis

\section{Introduction: IAPs are multi-faceted proteins}

The cellular inhibitor of apoptosis (IAP) gene family is defined by the presence of a canonical zinc-finger domain motif called baculovirus IAP repeat (BIR). The cellular IAPs also possess other domains that confer additional properties and functions (Budhidarmo and Day, 2015, Reed et al., 2004). The IAPs are found in baculoviruses and in all animal species. There are eight human IAP members with varied roles in cell division, cell motility, cell signaling, innate immunity, and apoptosis (LaCasse et al., 2015, and associated articles). Several IAPs are proto-oncogenes with transforming or tumor-supporting genetic alterations found in various cancers (Fulda and Vucic, 2012). The cancer promoting activities of the IAPs are counter-balanced by several tumor suppressors, some of which are direct IAP antagonists. Some IAP members possess RING and UBA functional domains, targeting other proteins with ubiquitin moieties in various configurations (Gyrd-Hansen and Meier, 2010). This post-translational modification typically results in either proteasomal-mediated degradation or in the formation of signaling complexes that recruit other key transducers or amplifiers of the signaling pathway. There may be additional changes in protein function arising from IAP-mediated ubiquitination, such as protein re-localization within the cell. The IAPs are typically viewed as suppressors of programmed cell death (apoptosis) as some family members can inhibit or suppress specific cell death proteases, the caspases. However, other IAP members critically regulate cell division and innate immunity, and this function is central to the role of the IAPs in cancer.

\footnotetext{
Abbreviations used in this paper: IAP, inhibitor of apoptosis; cIAP1, cellular inhibitor of apoptosis 1; cIAP2, cellular inhibitor of apoptosis 2; XIAP, X-linked inhibitor of apoptosis; BIR, baculovirus IAP repeat; TLR, Toll-like receptor; ILP, isolated limb perfusion; BCG, bacillus Calmette-Guerin; IFN, interferon; TNF $\alpha$, tumor necrosis factor alpha; NF-KB, nuclear factor kappa-B; SMC, Smac mimetic compound; DR, death receptor; PBLs, peripheral blood leukocytes; HL, Hodgkin lymphoma; NK, natural killer; CIK, cytokine-induced killer; NPC, nasopharyngeal carcinoma; DCs, dendritic cells.
}

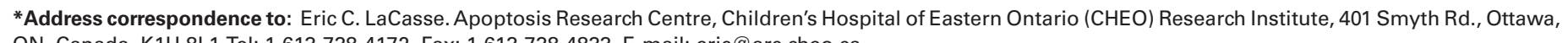
ON, Canada, K1H 8L1.Tel: 1-613-738-4172. Fax: 1-613-738-4833. E-mail: eric@arc.cheo.ca

Accepted: 6 May 2015.

ISSN: Online 1696-3547, Print 0214-6282 


\section{IAPs regulate life and cell death signaling by TNF superfamily members}

Two very similar and functionally redundant IAPs, CIAP1 and clAP2, are ubiquitin ligases that control TNF $\alpha$ and related cytokine member signaling through the classical or alternative NF-KB pathways (Beug et al., 2012). clAP1 and clAP2 bind to TRAF1 or TRAF2 and can be coupled to TNF superfamily receptors or effector kinases via TRAF1 or 2 bridging interactions, in some cases involving TRAF3. The clAPs activate the classical NF-KB pathway by ubiquitinating RIP1, thereby forming the TNFR-RIP1 signalosome. The signalosome then recruits other ubiquitin ligases and kinases to activate classical NF-KB signaling, which leads to the induction of survival, proliferative and inflammatory gene products (Fig. 1A). Conversely, in the absence of the cIAPs, TNF $\alpha$ signaling promotes the formation of RIP1-containing death complexes (lacking ubiquitin moieties on RIP1) called the ripoptosome and in some cases can lead to the formation of the necrosome (involving RIP3). These IAP-regulated death complexes can induce either caspase-8-mediated apoptosis or necroptosis, respectively (Fig. 1B). Hence, by suppressing the activation of the ripoptosome or preventing necroptosis and by stimulating NF-KB-responsive genes, the ClAPs represent critical decision points in determining life and death upon TNF $\alpha$ stimulation. In a clAP-deficient context, tumor cells frequently exhibit a predisposition to apoptosis over normal cells. Another

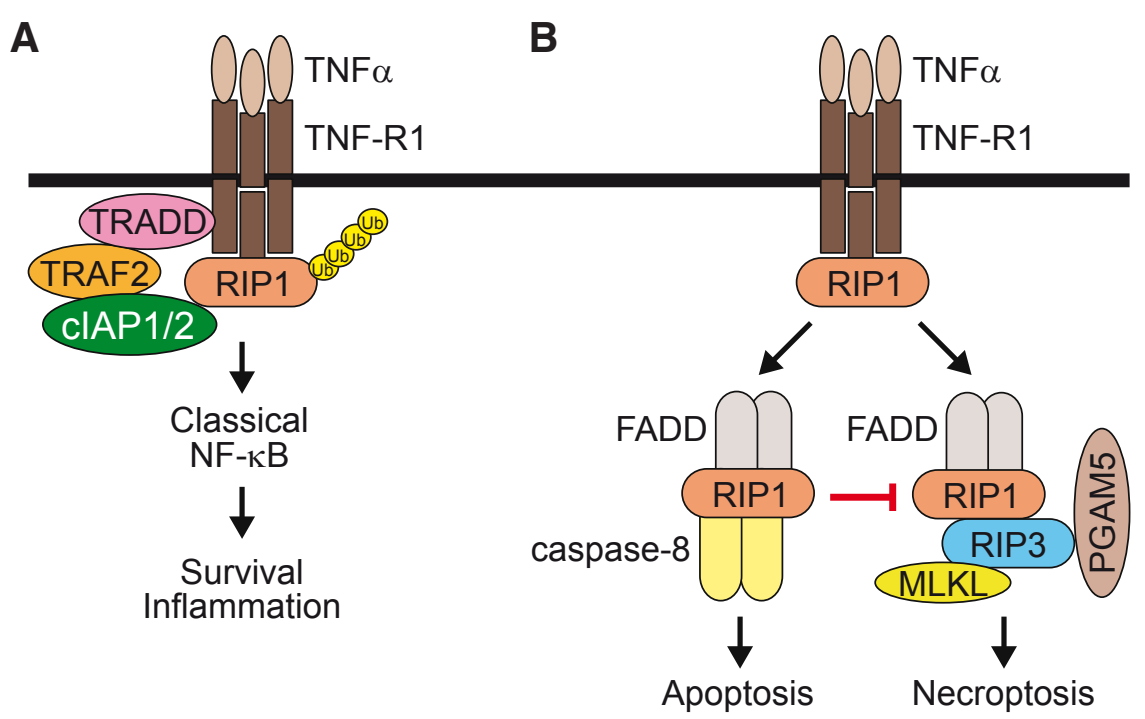

Fig. 1. Regulation of TNF-TNFR1 survival and death pathways in cancer cells by cIAP1, cIAP2 and Smac mimetic compounds. Shown is a simplified model of the pathways activated by TNF $\alpha$ binding to its receptor TNFR1 on a cancer cell (A). Normally receptor engagement by the ligand triggers recruitment of the CIAPS, CIAP1 and/or CIAP2 via TRAF2 and TRADD, to the TNFR1 and induces the K63-branched polyubiquitination of RIP1. This ubiquitination of RIP1 creates a signaling scaffold to recruit other kinases and ubiquitin ligases. This ultimately results in classical (or canonical) NF-KB activation and signaling. The NF-KB heterodimers enter the nucleus to induce the expression of genes related to cell survival, proliferation or inflammation (B). Alternatively, under conditions for which the cIAPs are absent, such as chemically-induced depletion with a Smac mimetic compound (SMC), RIP1 is no longer ubiquitinated and forms a default death complex, called the ripoptosome, which activates the initiator cell-death caspase-8 that can activate effector caspases leading to apoptosis. In addition, if caspase-8 is lost, RIP1 can form another death-inducing complex with RIP3, called the necrosome, which can lead to an alternate form of cell death called regulated necrosis or necroptosis. In either case, SMC and TNF $\alpha$ addition results in the death of a cancer cell.
IAP with ubiquitin ligase activity, $X$-linked IAP (XIAP), can also influence TNF $\alpha$ signaling and NF-KB activation. XIAP binding to XIAP enhances the kinase TAK1 activation of NF-KB. Notably, -7 , which are activated by caspase- 8 . Therefore XIAP can also control, at a distal nexus, the induction of apoptosis mediated by TNF $\alpha$. Moreover, XIAP is a potent suppressor of TRAIL-induced

(Albeck et al., 2008, Cummins et al., 2004).

Both ClAP1 and CIAP2 suppress the alternative NF-KB path-

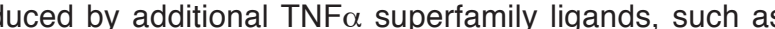
2012). Th or TWEAK (Beug et al., 2012, Varfolomeev NIK for proteasomal-mediated degradation. However, upon ligand binding to the cognate TNFR superfamily member, the APs and TRAFs are recruited to the receptor, which results in NiK stabilization and IKK $\alpha$ signaling. As a result, NF-KB-induced proliferative, survival and inflammatory genes are expressed in

\section{IAP antagonists sensitize tumors to TNF- and TRAIL-}

The commitment of a cell to death occurs in part with the release of a large processed mitochondrial protein, called second mitochondrial activator of caspases (Smac) (Du et al., 2000). Smac cytoplasmic IAPs and targets them for either ubiquitin-mediated proteasomal degradation (in the case of clAP1 and clAP2) or competes with caspase binding and inhibition (in the case of XIAP). The interaction between the exposed new $\mathrm{N}$-terminal sequence of Smac with the IAPs maps to a four amino acid sequence, AVPI, which is conserved in several other IAPbinding proteins such as caspase-9. This peptide binds to surface grooves on the BIR2 and BIR3 domains of the IAPs. Chemical synthetic mimetics of the Smac tetrapeptide structure have been developed to increase stability and cell penetration characteristics. We will refer to these as Smac mimetic compounds (SMCs) hereafter. SMCs recapitulate many of the actions of the Smac polypeptide. For example, the SMC-mediated loss of cIAPs specifically sensitizes tumor cells to apoptosis by extrinsic death ligands from the immune system, such as TNF $\alpha$ (Fig. 1B), TRAIL, LT $\alpha$ and FasL (e.g., Li et al., 2004). As single agents, SMCs are toxic to $5-15 \%$ of tumor cell lines, as those cell lines can produce TNF $\alpha$ endogenously. However, SMC cytotoxicity can be increased to $50 \%$ or more of cancer cell lines with the addition of exogenous recombinant TNF $\alpha$ or TRAIL (Benetatos et al., 2014, Cheung et al., 2009).

At least seven structurally different SMCs have entered clinical trials for cancer therapy to date, and these compounds have proven to be safe and well tolerated in phase 1 studies (Table 1) (Bai et al., 2014, Dhuria et al., 2013, Erickson et al., 2013, Infante et al., 2014, Wong 
et al., 2012). SMCs can be broadly classified as either monovalent or bivalent structures based on the number of IAP binding moieties present, either one or two units, respectively. The bivalent structures represent homodimers of monovalent units tethered together through a linker region. As stand-alone agents, SMCs demonstrate limited efficacy in the highly refractory and relapsed cancer patient population enrolled in phase $1 / 2$ clinical studies. This finding is not unexpected given that most tumor cell lines require an additional death ligand for killing by SMCs to occur in vitro. Therefore, for SMCs to be effective in the clinic, they will likely require an endogenous or exogenous source of death ligand. We discuss multiple approaches as to how this can be clinically achieved based on results from preclinical studies.

\section{Smac mimetic-mediated synergistic killing of cancer cells with death ligands induced by various immune triggers}

\section{Smac mimetic-mediated induction of cytokines and che- mokines}

Interestingly, SMCs themselves mediate the induction of systemic cytokines (such as IL8, TNF $\alpha$ ) and chemokines (such as MCP1, RANTES, CXCL1) when administered to animals or humans at very high doses (e.g., Kearney et al., 2013). The doselimiting toxic effects observed in vivo for SMCs relate primarily to TNF $\alpha$ production and its consequences (Bai et al., 2014, Erickson et al., 2013, Infante et al., 2014). Therefore, dosing has been reduced in clinical trials to avoid issues related to cytokine release syndrome. However, the production of TNF $\alpha$ may be needed to achieve anti-tumor responses in SMC clinical trials, and therefore a proper balance between acceptable toxicity and efficacy is likely required. Alternatively, approaches that rely on the induction of TNF $\alpha$ locally, within the tumor environment, may improve potency with overall less adverse side effects.

High-dose SMC treatment may have unintended consequences that can lead to cytokine release syndrome or to blunting of tumor responses to the death ligands. Mice genetically deleted in the hematopoietic compartment of the three IAPs, CIAP1, CIAP2 and XIAP, which are the targets of SMCs, demonstrate a pronounced cytokine release syndrome (Wong et al., 2014). This is attributed to the ability of these IAPs to restrain RIP1- and RIP3-dependent cytokine production. In addition, mice deficient in XIAP can also demonstrate a hyperinflammatory state in response to certain pathogens, such as Candida albicans (Hsieh et al., 2014). These XIAP-deficient mice mirror responses seen in male humans that carry inactivating mutations in XIAP, a primary immunodeficiency syndrome, called X-linked lymphoproliferative disease type 2 (XLP2) (Rigaud et al., 2006). XLP2 individuals experience treatment refractory Crohn's-like colitis due to immune defects in NOD1/2-RIP2 signaling (Pedersen et al., 2014). The disease is also associated with inappropriate macrophage activation. Altogether, these findings suggest that SMC targeting of XIAP at high doses may be responsible for some of the observed effects in humans. Further study is warranted to clarify this issue.

\section{Smac mimetic synergy with chemo- or radio-therapy medi- ated induction of cytokines}

Several chemotherapeutic agents, such as Doxorubicin and Irinotecan, are known to weakly activate NF-KB and to induce TNF $\alpha$ and other cytokines. Combinations of SMCs and chemotherapeutics have shown efficacy in vitro and in animal tumor models and some are being currently evaluated in the clinic (Table 1). Other chemotherapeutic agents also have additional immunomodulatory properties, such as cyclophosphamide (Wu and Waxman, 2014). Cyclophosphamide is being used in conjunction with a monovalent SMC in a clinical trial for multiple myeloma, based on highly promising data employing a transgenic mouse model (Chesi et al., 2013). Alternatively, the focal delivery of radiation to a tumor provokes a localized inflammatory response, which together with an SMC may provide the necessary cell death signal (Hill et al., 2011). However, in the presence of an SMC, it is unreasonable to assume that these somewhat indiscriminate approaches will be able to induce the proper level of cytokines required to adequately reduce overall tumor burden, particularly in patients with metastatic disease. To augment the tumoricidal effect of SMCs, novel approaches have been studied in preclinical models of cancer. These strategies enhance the delivery of death ligands within dispersed tumor microenvironments.

\section{Smac mimetic synergy with virus infection}

We hypothesized that viral infection of tumor-bearing animals may provide the necessary induction of local and systemic cytokines to act in combination with SMCs. Replicating oncolytic viruses are being developed as a potentially safe and targeted tumor immunotherapeutic approach (Lichty et al., 2014). We therefore evaluated several candidate oncolytic viruses with

TABLE 1

SMAC MIMETIC COMPOUNDS IN THE CLINIC

\begin{tabular}{|c|c|c|c|c|}
\hline $\begin{array}{l}\text { Smac mimetic compound } \\
\text { (alternate names) }\end{array}$ & Structural class & Developing company (partners) & $\begin{array}{l}\text { Combination agent trials } \\
\text { (accessory drugs shown for listed trials) }\end{array}$ & References \\
\hline RG7419 (GDC-0152) & monovalent & Roche-Genentech & $?$ & $\begin{array}{l}\text { (Erickson et al., 2013, Flygare et al., 2012, } \\
\text { Wong et al., 2012) }\end{array}$ \\
\hline CUDC-427 (GDC-0917) & monovalent & Curis (Genentech) & $?$ & (Wong et al., 2013) \\
\hline AEG40826 (HGS1029) & bivalent & Aegera/Pharmascience & $?$ & \\
\hline LCL161 & monovalent & Novartis & Paclitaxel, Cyclophosphamide, Gemcitabine & (Dhuria et al., 2013, Infante et al., 2014) \\
\hline Debio1143 (AT-406) & monovalent & DebioPharma (Ascenta) & $\begin{array}{l}\text { Daunorubicin + Cytarabine, Cisplatin, } \\
\text { Carboplatin + Paclitaxel }\end{array}$ & (Cai et al., 2011) \\
\hline APG1387 (SM1387) & bivalent & Ascentage (Ascenta) & $?$ & \\
\hline Birinapant (TL32711) & bivalent & Tetralogic & $\begin{array}{l}\text { 5-Azacitidine, Gemcitabine, Conatumumab, } \\
\text { Antiviral therapy }{ }^{\star *} \text { (Tenofovir or Entecavir) }\end{array}$ & (Benetatos et al., 2014, Condon et al., 2014) \\
\hline
\end{tabular}


SMCs in vitro for their combined anti-cancer effects (Beug et al., 2014). We found that members of the rhabdovirus family were particularly effective at synergizing with SMCs to kill tumor cells in vitro and in vivo, including models refractory to virus-mediated cancer killing (Beug et al., 2014). This effect is mediated by the systemic induction of type I interferons, such as IFN $\beta$, and by TNF $\alpha$ in mice in a manner that does not require infection of all the tumor cells. A diffusible cytokine storm induced by virus infection results in bystander death of non-infected tumor cells in the presence of an SMC. The synergy was remarkable and depending on the model, up to 10,000-fold increased sensitivity toward virus-mediated death was observed. The combination was well tolerated by the animals - SMCs did not hinder the anti-viral responses in vivo and the infections were well controlled in immunocompetent animals as expected for these attenuated oncolytic vectors. The excellent activity of the rhabdoviruses in combination with SMCs is postulated to be due to the capability of the virus to induce a strong type I IFN response, especially for attenuated variants, which carry mutations that enhance the host IFN response (such as those mutations in the VSV Matrix protein). This study was also the first report to show that type I or II IFNs could synergize with SMCs, likely via their secondary induction of TNF $\alpha$ in vivo (Beug et al., 2014). However, other death-inducing effects of IFN are possible and may play a role in the combination effects.

\section{Smac mimetic synergy with ligands for Toll-like receptors}

Viral infection stimulates the production of cytokines through Toll-like receptor (TLR) pathways and other IFN-producing pathways. We asked whether synthetic ligands that activate TLRs could replace the virus in our models, and would thus synergize with SMCs. TLR3 agonists such as poly(I:C), which mimic viral double stranded RNA, and TLR9 agonists such as CpG oligodeoxynucleotides, which mimic bacterial DNA, effectively synergize with SMCs in various in vitro and in vivo tumor models without the need for a 'live' virus infection (Beug et al., 2014). Previous reports also demonstrate that SMCs can kill tumor cells in vitro in combination with TLR agonists in a caspase8-dependent manner (Estornes et al., 2012, Friboulet et al., 2010, Friboulet et al., 2008, Verillaud et al., 2012, Weber et al., 2010). Enhanced killing in vitro is observed for poly $(\mathrm{I}: \mathrm{C})$ and bivalent SMC combination for EBVassociated nasopharyngeal carcinomas (NPCs), which commonly overexpress clAP2 (Friboulet et al., 2008). This synergy allowed for lower concentrations of poly(I:C) to be used. In addition, this group demonstrated that poly $(\mathrm{I}: \mathrm{C})$ induces clAP2 expression in a variety of other cancer cells, and that the bivalent SMC and TLR3 agonist combination cooperatively inhibit the clonogenic growth in a large fraction of carcinoma and melanoma cell lines (Friboulet et al., 2010). Sensitization towards poly(I:C)-induction of apoptosis in melanoma cells is also achieved with a monovalent SMC (Weber et al., 2010). The more selective TLR3 agonist, poly $(\mathrm{A}: U)$, can also synergize with a bivalent SMC to kill NPCs (Verillaud et al., 2012). Lebecque and colleagues established in part the mechanistic details by which poly $(\mathrm{I}: \mathrm{C})$ stimulation of TLR3 induces apoptosis in lung cancer cells in conjunction with a SMC, and how this differs with TNF $\alpha$ induced killing (Estornes et al., 2012). They describe a caspase-8 death complex that associates with ligated TLR3; this reaction requires RIP1, which is negatively regulated by cIAP2-TRAF2-TRADD.

\section{Smac mimetic synergy with an infectious agent vaccine administration}

Vaccines consisting of inactivated, non-infectious or infectious viruses or bacteria are also capable of safely inducing cytokines in a host. Prophylactic vaccination strategies to provide immunity against pathological viruses have been administered routinely and safely for millions of adults and children over several decades, and vaccines could be engineered to work in conjunction with SMCs for cancer therapy. The level of multi-TLR stimulation by a vaccine may not be as strong compared to an infectious 'live' virus because of the lack of efficient TLR binding which is mostly intracellular (endosomal) based. Recently, a novel approach employs the use of highly bioactive non-replicating rhabdovirusderived particles (NRRPs), which apart from direct tumoricidal properties, are also known to induce the release of a plurality of cytokines which synergize with SMCs (Batenchuk et al., 2013). This agent retains cell-entry capacity, thus endosomal localization and efficient TLR ligation likely explains its cytokine induction profile. As NRRPs exhibit enhanced therapeutic index over live virus counterparts, the combinatorial use of SMCs and NRRPs represents a promising strategy to treat disseminated cancers. In addition, vaccines can induce localized TNF $\alpha$ production, such as the tuberculosis vaccine BCG, which is used to treat bladder cancer by instillation of BCG into the bladder to cause TNF-mediated cancer cell death (Vacchelli et al., 2012). BCG can also synergize with SMCs to kill bladder cancer cells in vitro using conditioned media from immune cells (Jinesh et al., 2012). This study reveals that TNF $\alpha$ secreted from BCG-stimulated neutrophils is the key mediator of the SMC anticancer action for this combination immunotherapy. Therefore, other vaccine approaches, which could provide systemic or local cytokine release, may show benefit in combination with an SMC to treat cancer.

\section{Smac mimetic synergy with adoptive immune-cell therapy and cancer vaccines}

SMCs demonstrate pleiotropic effects on the immune system due to the many roles IAPs play in cell signalling pathways involved in activation, survival, apoptosis and differentiation. For example, SMCs can augment the anti-tumor activity of a melanoma cell cancer vaccine approach in mice by enhancing T-cell responses against the tumor (Dougan et al., 2010). This study showed that SMCs can augment both prophylactic and therapeutic antitumor vaccines in vivo, and that SMCs have co-stimulatory properties that lead to T-cell proliferation and activation. Another group demonstrated that SMCs can sensitize resistant hematological cancers and sarcomas to cytokine-induced killer (CIK) cell adoptive therapy (Rettinger et al., 2014). ClKs are peripheral blood leukocytes (PBLs), which are activated and expanded ex vivo by timed addition of cytokines to produce cells that have properties similar to natural killer (NK) cells. However, these researchers note that the bivalent SMC had an inhibitory effect on CIK and normal PBL survival. Therefore, improved tumor-targeted killing occurred when these cancers were preincubated with SMCs, with the drug removed prior to the addition of the CIKs. SMCs also potentiate Hodgkin lymphoma (HL) cell death by NK cells (Brinkmann et al., 2014). In a separate study, a monovalent SMC induced the expression of ligands for the activating immune receptor NKG2D on HL cells, and enhanced the susceptibility of HL cells to NKG2D-dependent lysis by NK cells (Sauer et al., 2013). 


\section{Additional immunomodulatory effects of SMCs}

SMCs demonstrate divergent immunomodulatory effects on human immune cell subsets, with implications for combination immunotherapy and tumor growth. Cebon and colleagues demonstrated that T-cells treated with a monovalent SMC enhanced cytokine secretion upon activation, with little effect on helper or cytotoxic T-cell survival or proliferation (Knights et al., 2013). Furthermore, they showed that a monovalent SMC treatment of peripheral blood mononuclear cells enhanced priming of naive T-cells with peptides in vitro yet intriguingly the dendritic cells (DCs) compartment underwent phenotypic maturation with a reduced capacity to cross-present a tumor antigen-based vaccine. Another group previously showed that a bivalent SMC could induce maturation of monocyte-derived DCs (Muller-Sienerth et al., 2011). This likely relates to the need for clAP1-dependent degradation of TRAF2 to allow CD40L-mediated differentiation of monocytes into macrophages (Dupoux et al., 2009), an effect that can be mimicked by SMC addition. It is also well established that chronic high-dose administration of an SMC can lead to monocyte/macrophage cell death in vitro and in vivo. For example, a bivalent SMC induced the death of freshly isolated human monocytes in vitro, while T-cells, DCs and macrophages were largely protected against SMC-induced killing (Muller-Sienerth et al., 2011). A different bivalent SMC induced apoptosis of murine bone-marrow derived macrophages in vitro and lead to the death of murine macrophages in vivo upon repeated high dose intraperitoneal injections (McComb et al., 2012). Interestingly, intraperitoneal administration of a bivalent SMC in murine ascites models of human ovarian carcinoma, or a murine sarcoma, caused a rapid inflammatory burst of TNF $\alpha$, IL $1 \beta$ and IFN $\gamma$ that was associated with the reversion of tumorassociated macrophages from a pro-tumoral M2 phenotype to a pro-inflammatory M1-like phenotype (Lecis et al., 2013). Another study with intraperitoneal injection of a bivalent SMC, followed by a TNF $\alpha$ injection, demonstrated an enhanced immune cell recruitment and inflammatory cytokine/chemokine burst in vivo at early time points (Kearney et al., 2013). This is associated with a massive recruitment of neutrophils to the peritoneum due to the accumulation of tumorous debris. SMC treatment leads to the elimination of ascites and prolonged survival in the ovarian cancer model and was curative in some cases for the murine sarcoma model (Lecis et al., 2013). These two tumor models are unresponsive to SMC treatment in vitro, demonstrating the need for immune cell recruitment and cytokine production for an effective SMC-mediated anti-tumor response. In a separate study, a monovalent SMC impaired the in vivo cytotoxic T-cell response of mice to LCMV virus infection (Gentle et al., 2014). In the same study, in vitro activated helper and cytotoxic T-cells were killed by the monovalent SMC, while naïve T-cells were not affected. XIAP inhibition was required for SMC-induced T-cell death, which is congruent with the well-known role that XIAP plays in preventing activation- and FasL-induced death in T-cells. In contrast, several studies have shown that SMCs do not impair oncolytic VSV control (Beug et al., 2014, Liu et al., 2013). Further work is required to validate and elucidate the mechanisms behind these apparent virus-specific effects.

\section{Smac mimetic synergy with recombinant cytokines (or other biologics)}

Recombinant IFNs are currently used for specific cancer, antiviral and multiple sclerosis therapy. Therefore, based on the virus and SMC combination therapy results, IFN could potentially be combined with SMCs to more effectively and broadly treat cancer. The combination cancer immunotherapy approach utilizing oncolytic rhabdoviruses in preclinical models relies clearly on IFN production for its anti-cancer effects (Beug et al., 2014). Recently, combinations of recombinant IFN $\alpha$ and a bivalent SMC were synergistically effective in killing acute myeloid leukemia (AML) cells (Bake et al., 2014), without untoward activity against normal peripheral blood lymphocytes. SMC and IFN $\alpha$ act in concert to stimulate the expression of TNF $\alpha$; its secretion into the tissue culture media mediate the AML-specific cell death.

Recombinant TNF $\alpha$ therapy is currently restricted to isolatedlimb perfusion (ILP) in combination with chemotherapy, which is used to treat mainly unressectable limb melanoma and sarcoma (Deroose et al., 2012). The TNF $\alpha$-ILP approach avoids systemic toxicity while improving early drug delivery to the tumor. Subsequent tumor-specific vascular endothelium damage augments the overall tumoricidal effect. ILP combinations with SMCs could likewise be applied to increase the tumor-killing effect of TNF $\alpha$. TRAIL receptor death ligands and receptor agonistic monoclonal antibodies, such as Conatumumab (AMG 655) are under clinical development for cancer; their combinatorial use with SMCs also represents interesting strategies to explore (Table 1).
1

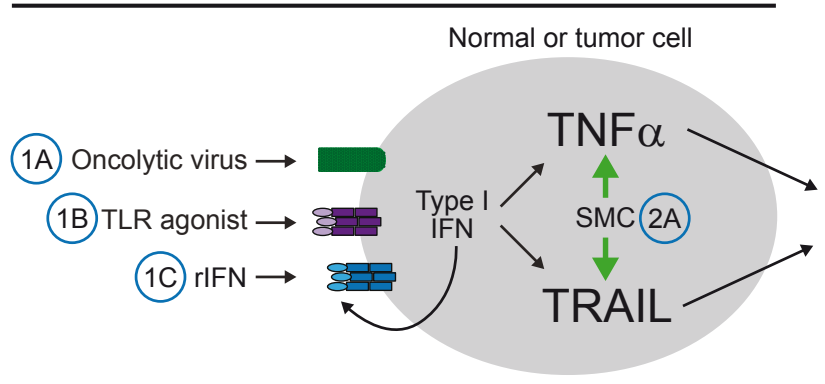

2

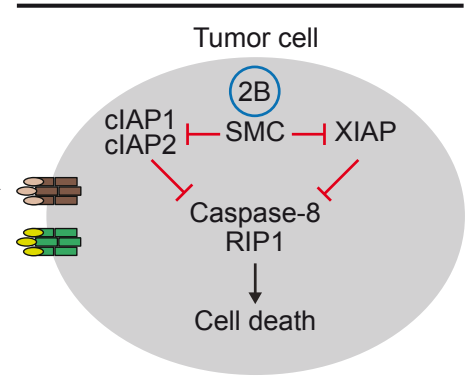

Fig. 2. One-two punch combination immunotherapy model involving IAP antagonists. The summary model shown illustrates the two-step approach for the combination immunotherapy with a Smac mimetic compound (SMC). In the first step (1), a tumor-bearing animal is given either a virus-derived agent (1A) or aTLR agonist (1B) to stimulate type 1 IFN production from normal cells (e.g. macrophage or

other) or tumor cells. The induced IFN can then stimulate the production of death ligands such as TNF $\alpha$ or TRAIL, and this effect may be enhanced in the presence of an SMC (2A). Alternatively, the need for an immune trigger can be substituted with the direct administration of recombinant interferon (rIFN) (1C). In the second phase (2), the addition of an SMC results in the death of a tumor cell in the presence of death ligands, as the loss of the clAPs switches TNF $\alpha$ signaling from a survival to a death pathway (2B). For those SMCs which also target XIAP, there may be added benefit to tumor cell killing by relieving the caspase-3/7 inhibitory effects of XIAP. The sequence of drug addition steps can be reversed or can occur simultaneously. 


\section{Conclusion: future prospects for IAP antagonism and combination cancer immunotherapy}

Several animal tumor models have shown that combination therapy using SMCs alongside novel or already-approved innate immune stimulants to induce cytokine production is a potent, highly feasible and broadly applicable anti-cancer strategy. We liken this combinatorial immunotherapeutic approach to the "onetwo punch" in boxing. The first punch stuns the opponent leaving them vulnerable to the greater devastation caused by the second blow (Fig. 2). Experience to date in the clinic has shown that neither agent, SMCs or the immune stimulant, is highly effective on its own at disabling its adversary; however, in combination they complement each other by providing the necessary cellular death cues to achieve a decisive 'knock-out' in preclinical models. Future combination clinical trial studies will ultimately reveal the utility of such an approach.

\section{Acknowledgements}

ECL and RGK are funded by the Canadian Institutes of Health Research. TA is funded by the Cancer Research Society (Canada) and the CHEO Foundation. RGK is a Distinguished Professor of the University of Ottawa, a Fellow of the Royal Society of Canada, and a scientific founder of Aegera Therapeutics (Montreal, Canada).

\section{References}

ALBECK, J.G., BURKE, J.M., ALDRIDGE, B.B., ZHANG, M., LAUFFENBURGER, D.A. and SORGER, P.K. (2008). Quantitative analysis of pathways controlling extrinsic apoptosis in single cells. Mol Cell 30: 11-25.

BAI, L., SMITH, D.C. and WANG, S. (2014). Small-molecule SMAC mimetics as new cancer therapeutics. Pharmacol Ther 144: 82-95.

BAKE, V., ROESLER, S., ECKHARDT, I., BELZ, K. and FULDA, S. (2014). Synergistic interaction of Smac mimetic and IFNalpha to trigger apoptosis in acute myeloid leukemia cells. Cancer Lett. 355: 224-231.

BATENCHUK, C., LE BOEUF, F., STUBBERT, L., FALLS, T., ATKINS, H.L., BELL, J.C., and CONRAD, D.P. (2013) Non-replicating rhabdovirus-derived particles (NRRPs) eradicate acute leukemia by direct cytolysis and induction of antitumor immunity. Blood Cancer J 3: e123.

BENETATOS, C.A., MITSUUCHI, Y., BURNS, J.M., NEIMAN, E.M., CONDON, S.M., YU, G., SEIPEL, M.E., KAPOOR, G.S., LAPORTE, M.G., RIPPIN, S.R. et al., (2014). Birinapant (TL32711), a bivalent SMAC mimetic, targets TRAF2-associated clAPs, abrogates TNF-induced NF-kappaB activation, and is active in patientderived xenograft models. Mol Cancer Ther 13: 867-879.

BEUG, S.T., CHEUNG, H.H., LACASSE, E.C. and KORNELUK, R.G. (2012). Modulation of immune signalling by inhibitors of apoptosis. Trends Immuno/33: 535-545.

BEUG, S.T., TANG, V.A., LACASSE, E.C., CHEUNG, H.H., BEAUREGARD, C.E., BRUN, J., NUYENS, J.P., EARL, N., ST-JEAN, M., HOLBROOK, J. et al., (2014). Smac mimetics and innate immune stimuli synergize to promote tumor death. Nat Biotechnol 32: 182-190

BRINKMANN, K., HOMBACH, A., SEEGER, J.M., WAGNER-STIPPICH, D., KLUBERTZ, D., KRONKE, M., ABKEN, H. and KASHKAR, H. (2014). Second mitochondria-derived activator of caspase (SMAC) mimetic potentiates tumor susceptibility toward natural killer cell-mediated killing. Leuk Lymphoma 55: 645-651.

BUDHIDARMO, R. and DAY, C.L. (2015). IAPs: Modular regulators of cell signaling. Semin Cell Dev Biol 39: 80-90.

CAI, Q., SUN, H., PENG, Y., LU, J., NIKOLOVSKA-COLESKA, Z., MCEACHERN, D., LIU, L., QIU, S., YANG, C.Y., MILLER, R. et al., (2011). A potent and orally active antagonist (SM-406/AT-406) of multiple inhibitor of apoptosis proteins (IAPs) in clinical development for cancer treatment. J Med Chem 54: 2714-2726.

CHESI, M., GARBITT, V., PALMER, S. and BERGSAGEL, P.L. (2013). IAP Antagonists Are a Novel Class Of Immunomodulators That Induce Complete Response In Vk*MYC Myeloma By Stimulating Plasmacytoid Dendritic Cells To Secrete IFNa. Blood 122: 128-128.
CHEUNG, H.H., MAHONEY, D.J., LACASSE, E.C. and KORNELUK, R.G. (2009) Down-regulation of C-FLIP Enhances death of cancer cells by smac mimetic compound. Cancer Res 69: 7729-7738.

CONDON, S.M., MITSUUCHI, Y., DENG, Y., LAPORTE, M.G., RIPPIN, S.R., HAIMOWITZ, T., ALEXANDER, M.D., KUMAR, P.T., HENDI, M.S., LEE, Y.H. et al., (2014). Birinapant, a smac-mimetic with improved tolerability for the treatment of solid tumors and hematological malignancies. J Med Chem 57: 3666-3677.

CUMMINS, J.M., KOHLI, M., RAGO, C., KINZLER, K.W., VOGELSTEIN, B. and BUNZ, F. (2004). X-linked inhibitor of apoptosis protein (XIAP) is a nonredundant modulator of tumor necrosis factor-related apoptosis-inducing ligand (TRAIL)-mediated apoptosis in human cancer cells. Cancer Res 64: 3006-3008.

DEROOSE, J.P., EGGERMONT, A.M., VAN GEEL, A.N., DE WILT, J.H., BURGER, J.W. and VERHOEF, C. (2012). 20 years experience of TNF-based isolated limb perfusion for in-transit melanoma metastases: TNF dose matters. Ann Surg Oncol 19: 627-635.

DHURIA, S., EINOLF, H., MANGOLD, J., SEN, S., GU, H., WANG, L. and CAMERON, S. (2013). Time-dependent inhibition and induction of human cytochrome P4503A4/5 by an oral IAP antagonist, LCL161, in vitro and in vivo in healthy subjects. J Clin Pharmacol 53: 642-653.

DOUGAN, M., DOUGAN, S., SLISZ, J., FIRESTONE, B., VANNEMAN, M., DRAGANOV, D., GOYAL, G., LI, W., NEUBERG, D., BLUMBERG, R. et al., (2010). IAP inhibitors enhance co-stimulation to promote tumor immunity. J Exp Med 207: 2195-2206.

DU, C., FANG, M., LI, Y., LI, L. and WANG, X. (2000). Smac, a mitochondrial protein that promotes cytochrome $c$-dependent caspase activation by eliminating IAP inhibition. Cell 102: 33-42.

DUPOUX, A., CARTIER, J., CATHELIN, S., FILOMENKO, R., SOLARY, E. and DUBREZ-DALOZ, L. (2009). cIAP1-dependent TRAF2 degradation regulates the differentiation of monocytes into macrophages and their response to CD40 ligand. Blood 113: 175-185.

ERICKSON, R.I., TARRANT, J., CAIN, G., LEWIN-KOH, S.C., DYBDAL, N., WONG, H., BLACKWOOD, E., WEST, K., STEIGERWALT, R., MAMOUNAS, M. et al., (2013). Toxicity profile of small-molecule IAP antagonist GDC-0152 is linked to TNF-alpha pharmacology. Toxicol Sci 131: 247-258.

ESTORNES, Y., TOSCANO, F., VIRARD, F., JACQUEMIN, G., PIERROT, A., VANBERVLIET, B., BONNIN, M., LALAOUI, N., MERCIER-GOUY, P., PACHECO, Y. et al., (2012). dsRNA induces apoptosis through an atypical death complex associating TLR3 to caspase-8. Cell Death Differ 19: 1482-1494.

FLYGARE, J.A., BERESINI, M., BUDHA, N., CHAN, H., CHAN, I.T., CHEETI, S., COHEN, F., DESHAYES, K., DOERNER, K., ECKHARDT, S.G. et al., (2012) Discovery of a Potent Small-Molecule Antagonist of Inhibitor of Apoptosis (IAP) Proteins and Clinical Candidate for the Treatment of Cancer (GDC-0152). J Med Chem 55: 4101-4113.

FRIBOULET, L., GOURZONES, C., TSAO, S.W., MOREL, Y., PATUREL, C., TEMAM, S., UZAN, C. and BUSSON, P. (2010). Poly(I:C) induces intense expression of c-IAP2 and cooperates with an IAP inhibitor in induction of apoptosis in cancer cells. BMC Cancer 10: 327.

FRIBOULET, L., PIOCHE-DURIEU, C., RODRIGUEZ, S., VALENT, A., SOUQUERE, S., RIPOCHE, H., KHABIR, A., TSAO, S.W., BOSQ, J., LO, K.W. et al., (2008), Recurrent overexpression of C-IAP2 in EBV-associated nasopharyngeal carcinomas: critical role in resistance to Toll-like receptor 3-mediated apoptosis. Neoplasia 10: 1183-1194.

FULDA, S. and VUCIC, D. (2012). Targeting IAP proteins for therapeutic intervention in cancer. Nat Rev Drug Discov 11: 109-124.

GENTLE, I.E., MOELTER, I., LECHLER, N., BAMBACH, S., VUCIKUJA, S., HACKER G. and AICHELE, P. (2014). Inhibitors of apoptosis proteins (IAPs) are required for effective T-cell expansion/survival during antiviral immunity in mice. Blood 123: 659-668.

GYRD-HANSEN, M. and MEIER, P. (2010). IAPs: from caspase inhibitors to modulators of NF-kappaB, inflammation and cancer. Nat Rev Cancer 10: 561-574.

HILL, R.P., ZAIDI, A., MAHMOOD, J. and JELVEH, S. (2011). Investigations into the role of inflammation in normal tissue response to irradiation. Radiother Oncol 101: 73-79.

HSIEH, W.C., CHUANG, Y.T., CHIANG, I.H., HSU, S.C., MIAW, S.C. and LAI, M.Z (2014). Inability to resolve specific infection generates innate immunodeficiency syndrome in Xiap-/- mice. Blood 124: 2847-2857. 
INFANTE, J.R., DEES, E.C., OLSZANSKI, A.J., DHURIA, S.V., SEN, S., CAMERON, S. and COHEN, R.B. (2014). Phase I dose-escalation study of LCL161, an oral inhibitor of apoptosis proteins inhibitor, in patients with advanced solid tumors. $J$ Clin Oncol 32: 3103-3110.

JINESH, G.G., CHUNDURU, S. and KAMAT, A.M. (2012). Smac mimetic enables the anticancer action of BCG-stimulated neutrophils through TNF-alpha but not through TRAIL and FasL. J Leukoc Biol 92: 233-244.

KEARNEY, C.J., SHERIDAN, C., CULLEN, S.P., TYNAN, G.A., LOGUE, S.E., AFONINA, I.S., VUCIC, D., LAVELLE, E.C. and MARTIN, S.J. (2013). Inhibitor of apoptosis proteins (IAPs) and their antagonists regulate spontaneous and tumor necrosis factor (TNF)-induced proinflammatory cytokine and chemokine production. J Biol Chem 288: 4878-4890.

KNIGHTS, A.J., FUCIKOVA, J., PASAM, A., KOERNIG, S. and CEBON, J. (2013). Inhibitor of apoptosis protein (IAP) antagonists demonstrate divergent immunomodulatory properties in human immune subsets with implications for combination therapy. Cancer Immunol Immunother 62: 321-335.

LACASSE, E.C., BEUG, S.T. and KORNELUK, R.G. (2015). The inhibitors of apoptosis (IAPS): over 20 years of research into life and death. Sem Cell Dev Biol 39: 70-71.

LECIS, D., DE CESARE, M., PEREGo, P., CONTI, A., CORNA, E., DRAGO, C., SENECI, P., WALCZAK, H., COLOMBO, M.P., DELIA, D. et al., (2013). Smac mimetics induce inflammation and necrotic tumour cell death by modulating macrophage activity. Cell Death Dis 4: e920.

LI, L., THOMAS, R.M., SUZUKI, H., DE BRABANDER, J.K., WANG, X. and HARRAN, P.G. (2004). A small molecule Smac mimic potentiates TRAIL- and TNFalphamediated cell death. Science 305: 1471-1474.

LICHTY, B.D., BREITBACH, C.J., STOJDL, D.F. and BELL, J.C. (2014). Going viral with cancer immunotherapy. Nat Rev Cancer 14: 559-567.

LIU, S., CHEN, J., CAI, X., WU, J., CHEN, X., WU, Y.T., SUN, L. and CHEN, Z.J. (2013). MAVS recruits multiple ubiquitin E3 ligases to activate antiviral signaling cascades. Elife 2: e00785.

MCCOMB, S., CHEUNG, H.H., KORNELUK, R.G., WANG, S., KRISHNAN, L. and SAD, S. (2012). clAP1 and clAP2 limit macrophage necroptosis by inhibiting Rip1 and Rip3 activation. Cell Death Differ. 19: 1791-1801.

MULLER-SIENERTH, N., DIETZ, L., HOLTZ, P., KAPP, M., GRIGOLEIT, G.U., SCHMUCK, C., WAJANT, H. and SIEGMUND, D. (2011). SMAC mimetic BV6 induces cell death in monocytes and maturation of monocyte-derived dendritic cells. PLoS One 6: e21556.

PEDERSEN, J., LACASSE, E.C., SEIDELIN, J.B., COSKUN, M. and NIELSEN, O.H. (2014). Inhibitors of apoptosis (IAPs) regulate intestinal immunity and inflammatory bowel disease (IBD) inflammation. Trends Mol Med. 20: 652-665.

REED, J.C., DOCTOR, K.S. and GODZIK, A. (2004). The domains of apoptosis: a genomics perspective. Sci STKE 2004: re9.

RETTINGER, E., GLATTHAAR, A., ABHARI, B.A., OELSNER, S., PFIRRMANN, V., HUENECKE, S., KUCI, S., KREYENBERG, H., WILLASCH, A.M., KLINGEBIEL,
T. et al., (2014). SMAC Mimetic BV6 Enables Sensitization of Resistant Tumor Cells but also Affects Cytokine-Induced Killer (CIK) Cells: A Potential Challenge for Combination Therapy. Front Pediatr 2: 75.

RIGAUD, S., FONDANECHE, M.C., LAMBERT, N., PASQUIER, B., MATEO, V., SOULAS, P., GALICIER, L., LE DEIST, F., RIEUX-LAUCAT, F., REVY, P. et al., (2006). XIAP deficiency in humans causes an X-linked lymphoproliferative syndrome. Nature 444: 110-114.

SAUER, M., REINERS, K.S., HANSEN, H.P., ENGERT, A., GASSER, S. and VON STRANDMANN, E.P. (2013). Induction of the DNA damage response by IAP inhibition triggers natural immunity via upregulation of NKG2D ligands in Hodgkin lymphoma in vitro. Biol Chem 394: 1325-1331.

VACCHELLI, E., GALLUZZI, L., EGGERMONT, A., FRIDMAN, W.H., GALON, J., SAUTES-FRIDMAN, C., TARTOUR, E., ZITVOGEL, L. and KROEMER, G. (2012). Trial watch: FDA-approved Toll-like receptor agonists for cancer therapy. Oncoimmunology 1: 894-907.

VARFOLOMEEV, E., GONCHAROV, T., MAECKER, H., ZOBEL, K., KOMUVES, L.G., DESHAYES, K. and VUCIC, D. (2012). Cellular inhibitors of apoptosis are global regulators of NF-kappaB and MAPK activation by members of the TNF family of receptors. Sci Signal 5: ra22.

VERILLAUD, B., GRESSETTE, M., MOREL, Y., PATUREL, C., HERMAN, P., LO, K.W., TSAO, S.W., WASSEF, M., JIMENEZ-PAILHES, A.S. and BUSSON, P. (2012). Toll-like receptor 3 in Epstein-Barr virus-associated nasopharyngeal carcinomas: consistent expression and cytotoxic effects of its synthetic ligand poly(A:U) combined to a Smac-mimetic. Infect Agent Cancer 7: 36.

WEBER, A., KIREJCZYK, Z., BESCH, R., POTTHOFF, S., LEVERKUS, M. and HACKER, G. (2010). Proapoptotic signalling through Toll-like receptor-3 involves TRIF-dependent activation of caspase- 8 and is under the control of inhibitor of apoptosis proteins in melanoma cells. Cell Death Differ 17: 942-951.

WONG, H., BUDHA, N.R., WEST, K., BLACKWOOD, E., WARE, J.A., YU, R., DARBONNE, W.C., GOULD, S.E., STEIGERWALT, R., ERICKSON, R. et al., (2012). Dogs are more sensitive to antagonists of inhibitor of apoptosis proteins than rats and humans: a translational toxicokinetic/toxicodynamic analysis. Toxicol Sci 130: 205-213.

WONG, H., GOULD, S.E., BUDHA, N., DARBONNE, W.C., KADEL, E.E., 3RD, LA H., ALICKE, B., HALLADAY, J.S., ERICKSON, R., PORTERA, C. et al., (2013). Learning and confirming with preclinical studies: modeling and simulation in the discovery of GDC-0917, an inhibitor of apoptosis proteins antagonist. Drug Metab Dispos 41: 2104-2113.

WONG, W.W., VINCE, J.E., LALAOUI, N., LAWLOR, K.E., CHAU, D., BANKOVACKI, A., ANDERTON, H., METCALF, D., O'REILLY, L., JOST, P.J. et al., (2014). cIAPs and XIAP regulate myelopoiesis through cytokine production in an RIPK1- and RIPK3-dependent manner. Blood 123: 2562-2572.

WU, J. and WAXMAN, D.J. (2014). Metronomic cyclophosphamide schedule-dependence of innate immune cell recruitment and tumor regression in an implanted glioma model. Cancer Lett 353: 272-280. 


\section{Further Related Reading, published previously in the Int. J. Dev. Biol.}

Revisiting DNA damage repair, p53-mediated apoptosis and cisplatin sensitivity in germ cell tumors

Francesca Cavallo, Darren R. Feldman and Marco Barchi

Int. J. Dev. Biol. (2013) 57: 273-280

http://dx.doi.org/10.1387/ijdb. 130135mb

Tumor-associated macrophages in breast cancer: distinct subsets, distinct functions

Laoui D, Movahedi K, Van Overmeire E, Van den Bossche J, Schouppe E, Mommer C, Nikolaou A, Morias Y, De Baetselier P, Van Ginderachter JA.

Int J Dev Biol (2011) 55: 861-867

http://dx.doi.org/10.1387/ijdb.113371dl

Life-giving caspases: revealing new roles during mouse embryo preimplantation development

Dolores Busso, Calixto Dominguez, Tomas Perez-Acle and Ricardo D. Moreno

Int. J. Dev. Biol. (2010) 54: 857-865

http://dx.doi.org/10.1387/ijdb. 092921db

Apoptosis in Drosophila: compensatory proliferation and undead cells Francisco A. Martín, Ainhoa Peréz-Garijo and Ginés Morata

Int. J. Dev. Biol. (2009) 53: 1341-1347

http://dx.doi.org/10.1387/ijdb. 072447fm

Key apoptosis regulating proteins are down-regulated during postnatal tissue development

Shane D. Madden, Maryanne Donovan and Thomas G. Cotter

Int. J. Dev. Biol. (2007) 51: 415-424

http://dx.doi.org/10.1387/ijdb. 062263sm

A generalized caspase inhibitor disrupts early mammalian development

Zakeri Z, Lockshin RA, Criado-Rodríguez LM, Martínez-A C

Int J Dev Biol (2005) 49: 43-47.

http://dx.doi.org/10.1387/ijdb.041920zz

5 yr ISI Impact Factor $(2013)=2.879$
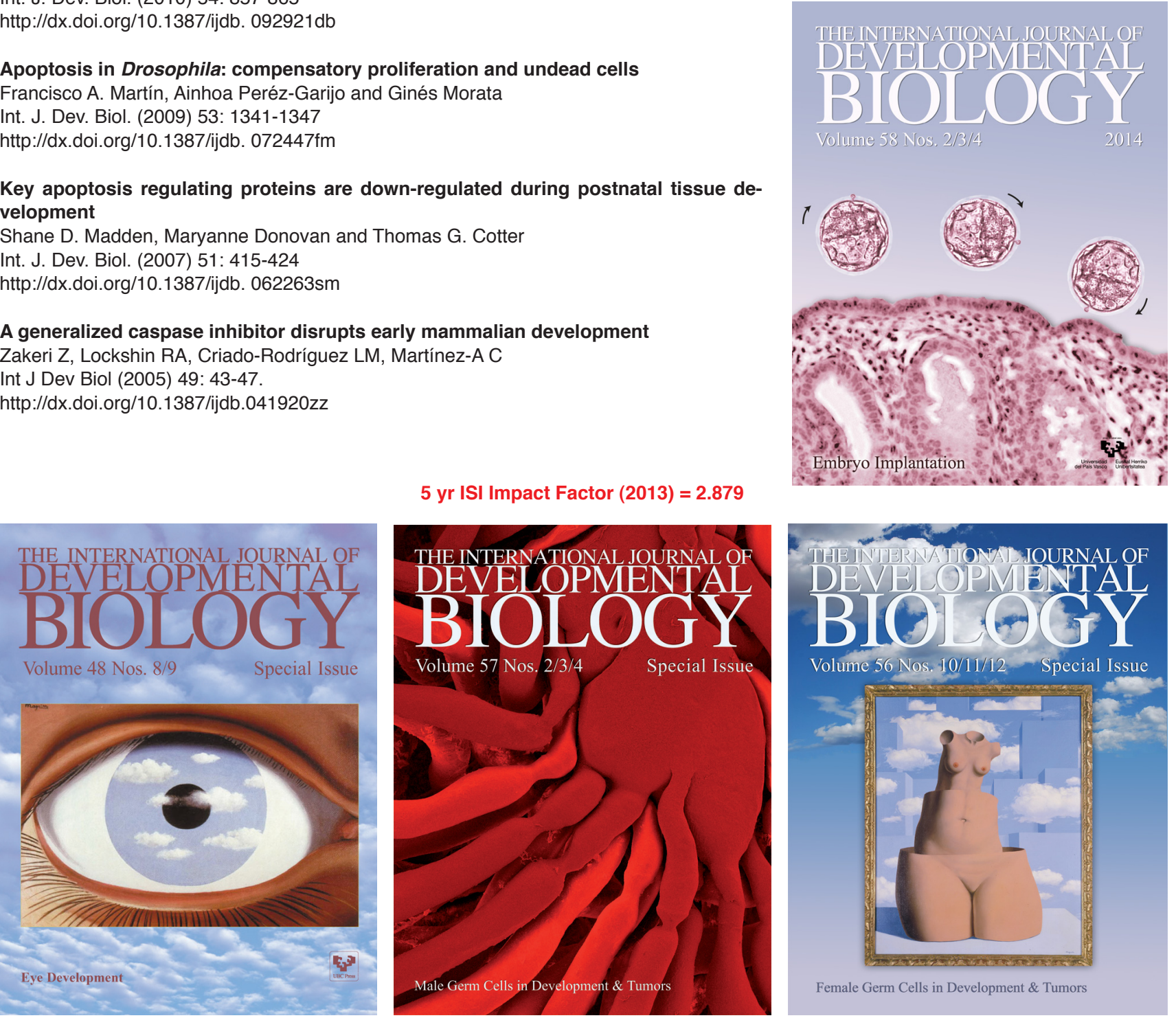